\title{
The origin of mafic-ultramafic bodies within the northern Dashwoods Subzone, Newfoundland Appalachians
}

\author{
C. Johan Lissenberg ${ }^{1, *}$, Vicki J. McNicoll ${ }^{2}$ and Cees R. van Staal ${ }^{1,2}$ \\ 1. Department of Earth Sciences, University of Ottawa, and Ottawa-Carleton Geoscience Centre, \\ 140 Louis Pasteur, Ottawa, ON K1N 6N5, Canada. \\ 2. Geological Survey of Canada, NRCan, 601 Booth Street, Ottawa, ON K1A 0E8, Canada. \\ * Corresponding author; Current address: Department of Geology and Geophysics, Woods Hole Oceanographic Institute, \\ 360 Woods Hole Road MS \#8, Woods Hole MA 02543
}

Date received: 27 January 2005 I Date accepted: 14 June 2005

\begin{abstract}
Mafic-ultramafic bodies of possible ophiolitic origin are widespread within the northern part of the Dashwoods Subzone of the Newfoundland Appalachians. The bodies fall into two types; the first consists of relatively undeformed, fresh, layered gabbroic bodies, which contrasts with the second that consists of metamorphosed ultramafic lithologies. Two of the largest gabbroic bodies yielded U-Pb zircon ages of $432.4 \pm 1.0$ and $429.9 \pm 1.2 \mathrm{Ma}$. Their Silurian age refutes an ophiolitic origin, and, along with their hydrous nature and fresh character, indicates that they formed in the widespread Early Silurian igneous event that affected both the Dashwoods and Notre Dame subzones. Our new data further substantiate the bimodal character of the Silurian event. The ultramafic bodies are inferred to be of ophiolitic origin. Those that occur in the Dashwoods subzone are interpreted to be related to the Lushs Bight oceanic tract, whereas those in the Lloyds River Fault Zone are correlated with the Annieopsquotch ophiolite belt.
\end{abstract}

\section{RÉSUMÉ}

Des masses mafiques-ultramafiques d'origine possiblement ophiolitique sont répandues à l'intérieur de la partie septentrionale de la sous-zone de Dashwoods des Appalaches à Terre-Neuve. Les masses s'insèrent dans deux catégories : la première est constituée de masses gabbroïques stratifiées, récentes, relativement peu déformées, qui tranchent avec la seconde, constituée de lithologies ultramafiques métamorphisées. Deux des masses gabbroïques les plus vastes ont affiché des âges de 432,4 $\pm 1,0$ et de 429,9 $\pm 1,2 \mathrm{Ma}$ par datation U-Pb sur zircon. Leur âge silurien réfute une origine ophiolitique et, de pair avec leur nature aqueuse et leur caractère récent, signale qu'elles se sont formées au cours du processus igné étendu du Silurien précoce ayant affecté les sous-zones de Dashwoods et de Notre Dame. Nos nouvelles données attestent davantage le caractère bimodal de l'événement silurien. On suppose que les masses ultramafiques sont d'origine ophiolitique. Les masses présentes dans la sous-zone de Dashwoods sont interprétées comme des unités apparentées à la parcelle océanique de Lushs Bight tandis que celles se trouvant dans la zone de la faille de la rivière Lloyds ont été corrélées avec la ceinture ophiolitique d'Annieopsquotch.

[Traduit par la rédaction]

\section{INTRODUCTION}

The Newfoundland Appalachians record the OrdovicianSilurian closure of the Iapetus Ocean, which led to juxtaposition of Laurentia with several peri-Gondwanan continental blocks. Rocks that originated within the peri-Laurentian oceanic realm of Iapetus are widespread and constitute the Notre Dame and Dashwoods subzones (Williams et al. 1988). Ophiolitic rocks are particularly abundant in these subzones, and occur in three large ( $>200 \mathrm{~km}$ by $5-20 \mathrm{~km}$ ) well-exposed Cambrian-Early Ordovician belts (Fig. 1). The ophiolites mark the opening and destruction of subduction-related basins, and as such contain important information regarding the tectonic development of the orogen. Mafic to ultramafic bodies of possible ophiolitic affinity, ranging in size from $100 \mathrm{~m}^{2}$ to $30 \mathrm{~km}^{2}$, occur throughout both subzones (Fig. 1). However, their poorly exposed contact relationships, accompanied by the abundance of younger Ordovician-Silurian plutons, have hindered establishing their tectonic context and correlating them with the various ophiolite belts. The origin of these scattered and isolated mafic-ultramafic bodies has a bearing on tectonic models for ophiolite evolution within the Dashwoods and Notre Dame subzones, and hence on tectonic models for these subzones as a whole. This paper presents field and petrographic observations, as well as U-Pb ages, from several bodies with the objective of resolving their origin. We will demonstrate that:(1) the bodies 


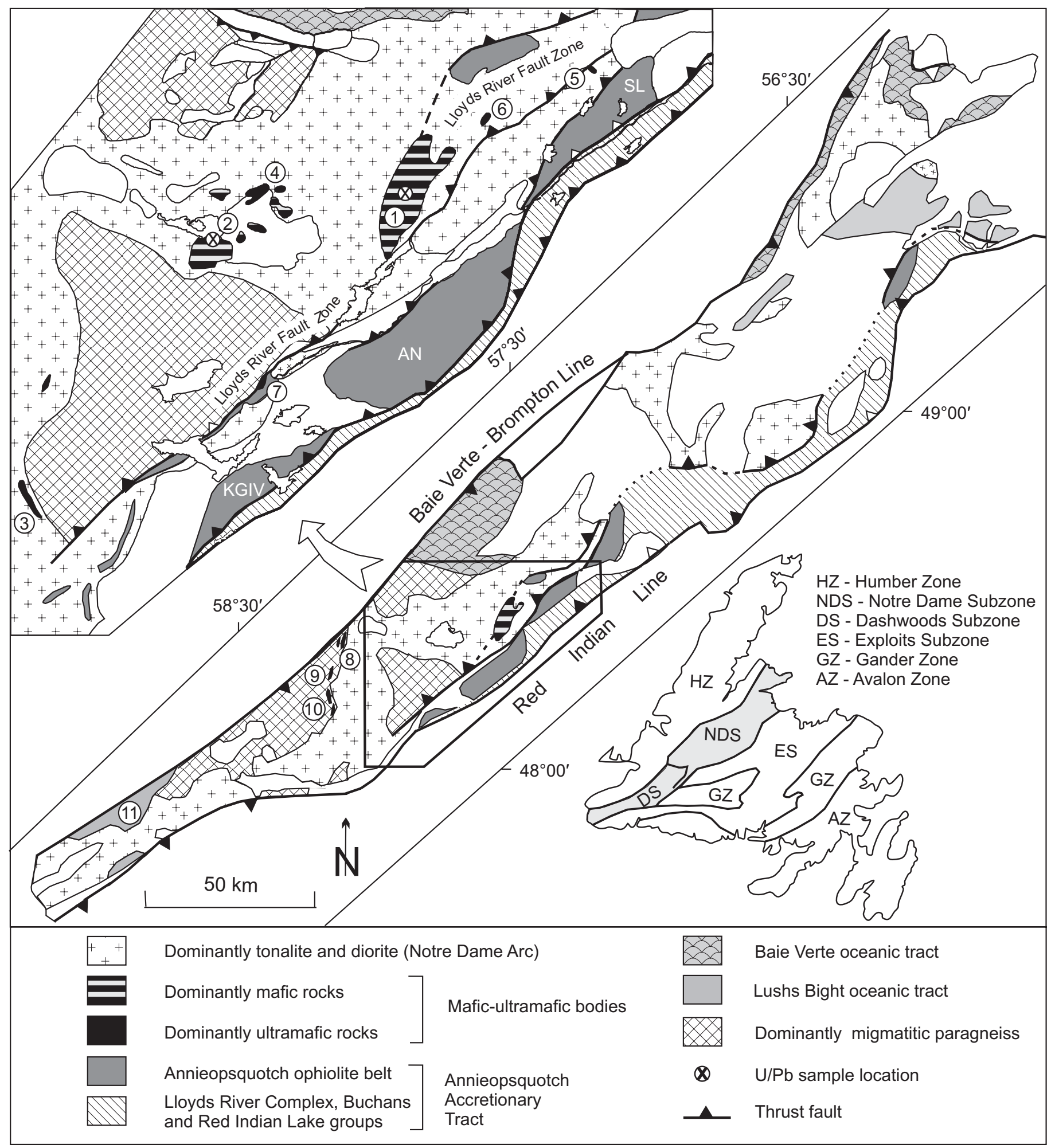

Fig. 1. Simplified geological map showing the distribution of pre-Silurian elements in the Dashwoods and Notre Dame subzones and the distribution of mafic-ultramafic bodies discussed herein. Inset shows close-up of study area. 1=Puddle Pond Complex; 2=John's Brook Lake gabbro; 3=Whaleback Pond; 4=Silver Pond; 5=Lake of the Hills; 6=Padille Pond; 7=Lloyds River; 8=Dennis Pond; 9=Three Ponds; 10=North Fischells Brook; 11=Long Range Complex. AN=Annieopsquotch ophiolite; KGIV=King George IV ophiolite; SL=Star Lake ophiolite. Modified from Colman-Sadd et al. (1990), Lissenberg et al. (2005 a) and van Staal et al. (2005 a,b,c). 
can be subdivided based on composition and metamorphic grade; (2) mafic bodies are of Silurian age, precluding an ophiolitic origin; and (3) dominantly ultramafic bodies represent ophiolitic slivers related to the Lushs Bight oceanic tract and Annieopsquotch ophiolite belt.

\section{REGIONAL GEOLOGY}

The closely related Dashwoods and Notre Dame subzones comprise rocks formed along the Laurentian margin of Iapetus. Both subzones are dominantly composed of the Late Cambrian to Lower Silurian Notre Dame Arc (Whalen et al. 1997; van Staal et al. 2003), paragneiss, arc-back arc complexes, and ophiolites (e.g., Swinden et al. 1997; Lissenberg et al. 2005 b). Post-tectonic late Lower to Upper Silurian magmatism is widespread, and is dominated by granite with subordinate mafic rocks (Currie and van Berkel 1989; Whalen 1989; Dunning et al. 1990; Whalen et al. 1996, 2003). Geochemical and isotopic data, inherited Proterozoic zircon grains, and tectonic relationships indicate that the Notre Dame Arc was formed on a rifted piece of the Laurentian margin, referred to as the Dashwoods microcontinent, which was separated from Laurentia by the Humber seaway in the Cambrian-Early Ordovician (Whalen et al. 1997; Waldron and van Staal 2001). The Humber Seaway was closed by east-directed subduction underneath the Dashwoods microcontinent in the Early Ordovician, generating the early phases of the Notre Dame Arc (van Staal et al. 2003). Closure of the Humber Seaway led to collision between the Dashwoods microcontinent and the Laurentian margin, leading to a period of shut-off of the Notre Dame Arc (van Staal et al. 2003) and initiation of west-directed subduction underneath the composite Laurentian margin (Lissenberg et al. 2005 c). This subduction zone was responsible for formation of several arc phases (e.g. Buchans) and ophiolites (e.g., Annieopsquotch, Skidder) that were subsequently accreted to the Laurentian Margin to form the Annieopsquotch Accretionary Tract (Lissenberg et al. 2005 b). The Annieopsquotch Accretionary Tract is separated from the Dashwoods microcontinent by the Lloyds River Fault Zone (Fig. 1), which comprises three amphibolite-facies high-strain zones separated by sheets of syn-kinematic plutonic rocks (Lissenberg and van Staal 2002). Accretion of the arc-back arc complexes along the Lloyds River Fault Zone started prior to $470 \mathrm{Ma}$, and lasted for ca. $20 \mathrm{Ma}$ (Lissenberg et al. $2005 \mathrm{~b}$ ). The contemporaneous flare-up of the Notre Dame Arc has been attributed to slab break-off of the oceanic portion of the Laurentian plate following Humber Seaway closure (Whalen et al. 2003; van Staal et al. 2003). After ca. 450 Ma the periLaurentian realm stabilized as orogenic activity concentrated in the peri-Gondwanan realm to the east.

\section{OPHIOLITE BELTS}

Ophiolitic rocks in the Dashwoods and Notre Dame subzones have been subdivided into three belts based on their age and tectonic evolution (Fig. 1; Swinden et al. 1997). The oldest generation of ophiolites, which are preserved in the Lushs Bight oceanic tract (508-501 Ma; Elliott et al. 1991; Szybinski 1995; Kurth et al. 1998), is comprised mostly of sheeted dykes and pillow basalts at Lushs Bight. Crosscutting, continentally contaminated ca. 501-488 Ma dykes indicate that the tract was already emplaced onto Laurentian continental crust in the Late Cambrian-Tremadoc (Szybinski 1995; Swinden et al. 1997). The ophiolitic Long Range Complex, which occurs near the southwest coast of Newfoundland (Fig. 1), comprises gabbro, pyroxenite, and relatively homogeneous harzburgites (mantle tectonite?). It is underlain by a metasedimentary mélange, termed the Mischief mélange, which includes blocks derived from the overlying ophiolite (Hall and van Staal 1999). The Long Range complex was emplaced onto the Dashwoods microcontinent prior to $488 \mathrm{Ma}$, because the ophiolite and underlying mélange are cut by the Cape Ray granodiorite of this age (Dubé et al. 1996). Based on their similar tectonic history, we interpret the Long Range complex to be correlative with the Lushs Bight ophiolite and therefore part of the Lushs Bight oceanic tract.

Obduction of the Lushs Bight oceanic tract was followed by generation of the Tremadoc (489-484 Ma; Dunning and Krogh 1985; Cawood et al. 1996; Kurth et al. 1998) Baie Verte oceanic tract during subduction in the Humber Seaway. The Baie Verte oceanic tract comprises complete ophiolite sequences such as Betts Cove (Upadhyay 1973; Coish and Church 1979; Bédard et al. 2000) and Bay of Islands (Dewey and Bird 1971; Malpas 1976; Karson and Dewey 1978; Jenner et al. 1991), as well as numerous dismembered ophiolitic fragments clustered mostly along the Baie Verte-Brompton Line (Fig. 1). These ophiolites formed basement to Tremadoc-Arenig intra-oceanic arc rocks of the Snooks arm and Glover groups (Upadhyay 1973; Szybinski et al. 1995; Bédard et al. 2000). The Baie Verte oceanic tract was subsequently emplaced onto the Laurentian margin during collision between the Dashwoods microcontinent and Laurentia (Waldron and van Staal 2001).

The third ophiolite belt, the Annieopsquotch ophiolite belt (Dunning and Chorlton 1985) was formed at 481-478 Ma (Dunning and Krogh 1985) during initiation of west-directed subduction zone outboard of the Dashwoods microcontinent (Lissenberg et al. $2005 \mathrm{c}$ ). This belt comprises three nearly complete ophiolites (Annieopsquotch, Star Lake and King George IV ophiolites), as well as related ophiolite fragments along strike (e.g. the Hall Hill complex and mafic enclaves within the Hungry Mountain complex; Lissenberg et al. 2005 c). It was juxtaposed with the Dashwoods microcontinent along the Lloyds River Fault Zone (Lissenberg and van Staal 2002)

Abundant mafic-ultramafic bodies within the Notre Dame and Dashwoods subzones range in size from $100 \mathrm{~m}^{2}$ to 30 $\mathrm{km}^{2}$. Although some bodies clearly represent enclaves within paragneiss or plutons of the Notre Dame Arc (Dunning and Chorlton 1985; Fox and van Berkel 1988), contact relationships of most are uncertain. Dunning and Chorlton (1985) interpreted all mafic-ultramafic enclaves as remnants of the Annieopsquotch ophiolite belt, which by their definition in- 
cluded the Long Range Complex. Fox and van Berkel (1988) speculated that some ultramafic enclaves represent relics of the Long Range mafic-ultramafic complex and/or Glover Group, whereas Currie and van Berkel (1989) suggested that some mafic bodies represent Silurian plutons, similar to intrusions previously recognized near the Annieopsquotch ophiolite (e.g., Dunning 1981; Dunning et al 1990) and Grand Lake (Whalen et al. 1987).

\section{DESCRIPTION OF THE MAFIC-ULTRAMAFIC BODIES}

Mafic-ultramafic bodies have been studied in the northern part of the Dashwoods Subzone and in the Lloyds River Fault Zone. Samples of the Long Range Complex have been studied for comparison. Major occurrences are summarized in Table 1 and Fig. 1. Based on compositional differences, as well as metamorphic grade, the studied bodies can be divided into two types.

The first type is dominantly gabbroic in composition, and rocks are generally fresh and rarely display penetrative fabrics. Ultramafic rocks are unknown from these bodies, and they are relatively large in size. The biggest is the Puddle Pond complex (ca. 10 by $3 \mathrm{~km}$ ), which occurs along the boundary between the Dashwoods Subzone and the Annieopsquotch Accretionary Tract (\#1 in Fig. 1). This complex is dominated by a layered cumulate sequence, that grades from troctolite through olivine gabbro to gabbro (Fig. 2a, b). Hornblende-bearing gabbro dominates the southwestern part of the complex. In addition, it contains olivine norite and associated troctolite, the position of which within the sequence is uncertain. Pegmatitic patches, with grain size up to $10 \mathrm{~cm}$, are common within gabbroic rocks. The complex is cut by granite of presumed Silurian age. The cumulate rocks are characterized by the ubiquitous presence of generally fresh, subhedral plagioclase. Olivine occurs in nearly all cumulates as sub- to anhedral grains, and is partly altered to serpentine or iddingsite. In more evolved cumulates, clinopyroxene is modally abundant, and is generally partly altered to green amphibole. Igneous brown amphibole is ubiquitous as rims around cumulus plagioclase, olivine and pyroxene, and locally forms interstitial grains. Minor orange-brown biotite is locally associated with brown amphibole. The presence of igneous amphibole and biotite suggests the magmas that generated the Puddle Pond complex were hydrous. Both on a macro- and microscopic scale, the gabbroic rocks are dissected by small fractures, which are lined with chlorite and green amphibole. A second large gabbroic body, the John's Brook Lake gabbro (also referred to as the Silver Pond complex), occurs ca. $20 \mathrm{~km}$ northwest of the Annieopsquotch ophiolite (\#2 in Fig. 1). It comprises undeformed to weakly deformed gabbro, with local igneous layering and pegmatitic patches, as well as hornblende gabbro. Contact relationships are not exposed, although it is cut by granite of presumed Silurian age. Several smaller gabbroic bodies are associated with the John's Brook Lake gabbro, and have similar characteristics (Fig. 1).
Based on the striking resemblance between the layered cumulates and gabbros of the Puddle Pond complex plus John's Brook Lake gabbro and the Annieopsquotch ophiolite, Dunning and Chorlton (1985) interpreted these complexes to be ophiolitic and related to the Annieopsquotch ophiolite belt. However, based on their fresh and undeformed nature, Currie and van Berkel (1989) favoured a Silurian plutonic origin.

The second type recognized in the mafic-ultramafic bodies is dominated by variably metamorphosed ultramafic rocks (lherzolite, harzburgite, wehrlite, dunite, and pyroxenite; Fig. 2c, d). They are commonly associated with (meta)gabbro, which appears to be both intrusive into, and interlayered with, the ultramafic rocks. Their size is generally restricted $(<1 \mathrm{~km})$. The body near Whaleback Pond (\#3 in Fig. 1) comprises websterite intruded by deformed lherzolite (Fig. 2c), as well as dunite, wehrlite, and minor metagabbro. The ultramafic rocks are composed of variably serpentinized olivine, clinopyroxene, orthopyroxene, and tremolite. The metagabbro is highly deformed, giving the rock a flaser gabbro-like appearance. It is composed of hornblende, which locally forms $\mathrm{cm}$-sized augen, and plagioclase. The body appears to be enclosed in tonalite of the Notre Dame Arc, although direct contact relationships have not been observed. West of Silver Pond, scattered outcrops within an area of ca. 1 by $1 \mathrm{~km}$ consist of (meta)harzburgite and minor dunite with associated gabbro (\#4 in Fig. 1). A smaller associated body occurs just to the east of it. These rocks are dominated by subhedral to euhedral partly serpentinized olivine enclosed in largely chloritized pyroxene oikocrysts. Minor plagioclase occurs interstitially. Tremolite is common, and magnesite and chromite occur as accessory phases. The ultramafic rocks are cut by granite of presumed Silurian age. On the southeast shore of Lake of the Hills, harzburgite and metapyroxenite (tremolite+chlorite+talc) occur amidst outcrops of Notre Dame Arc plutons (\#5 in Fig. 1). On the southeast shore of Padille Pond, several outcrops of variably metamorphosed lherzolite occur (\#6 in Fig. 1). The lherzolite is composed of olivine (mostly altered to iddingsite and serpentine) enclosed by blurry clinopyroxene oikocrysts. A more metamorphosed variety is characterized by tremolite in a matrix of serpentine, magnesite, and chlorite. Contact relationships are not directly exposed, but the body is surrounded by Middle Ordovician tonalite of the Notre Dame Arc. North of Lloyds River, a single outcrop of dunite occurs, which is enclosed in gabbro (\#7 in Fig. 1). The dunite is composed of olivine and tremolite, and is partly serpentinized. The ultramafic bodies have been interpreted as ophiolitic fragments of the Annieopsquotch ophiolite belt (Dunning and Chorlton 1985).

\section{GEOCHRONOLOGY}

\section{Analytical techniques}

We have dated two of the gabbroic bodies, the Puddle Pond complex and the John's Brook Lake gabbro, to test whether their age is compatible with an ophiolitic origin. Both samples 


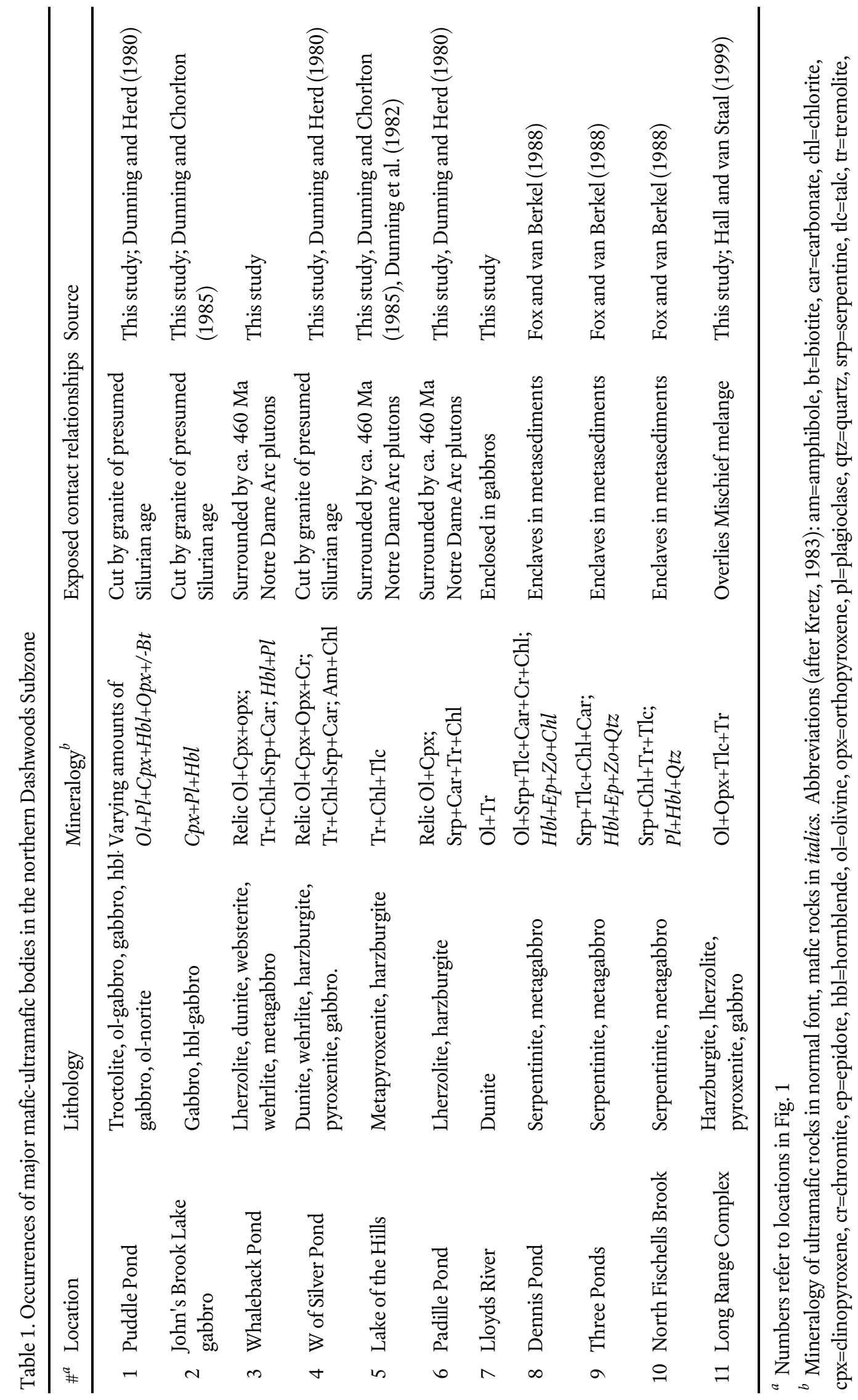



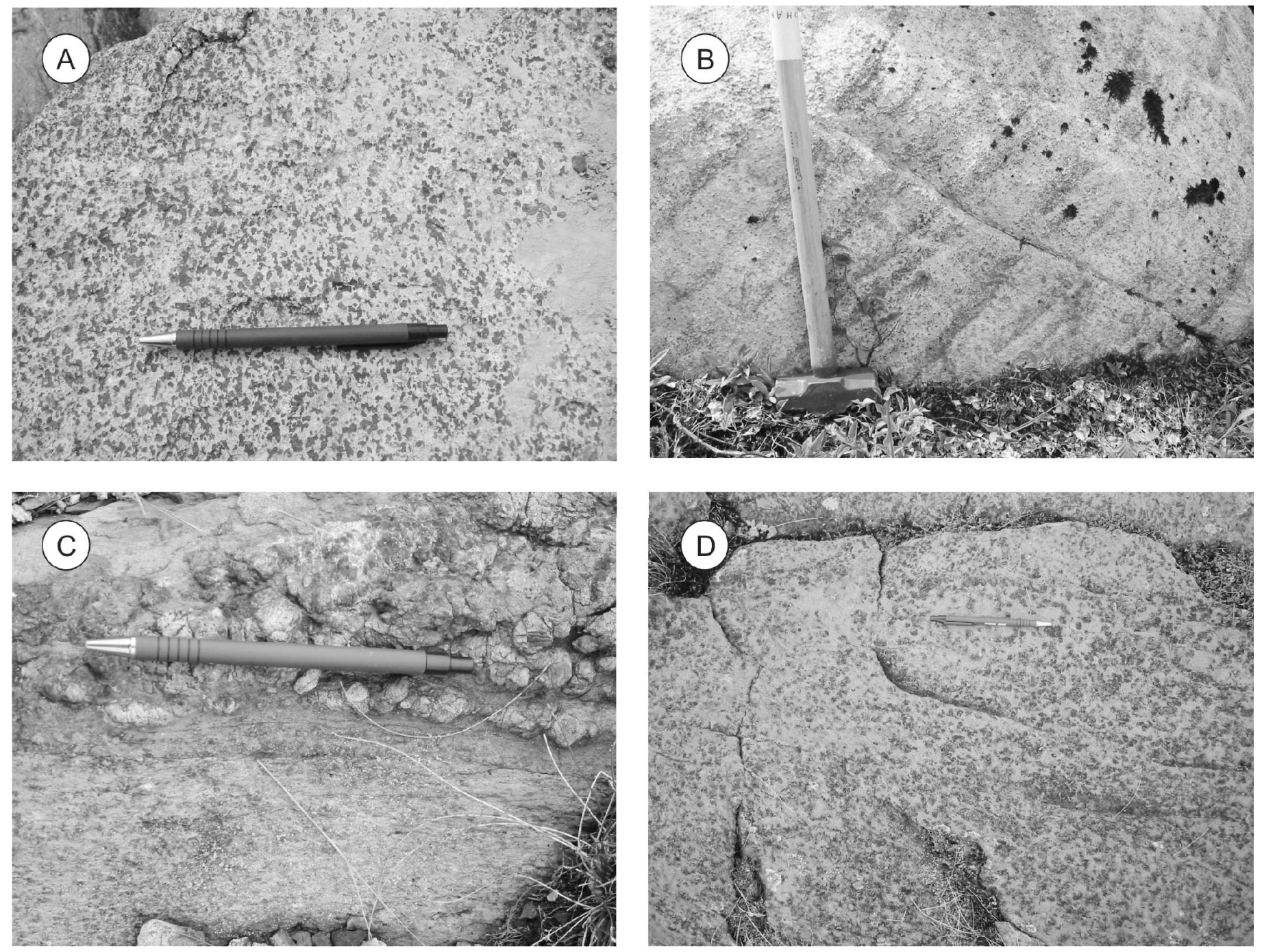

Fig. 2. Field photographs of mafic bodies within the Notre Dame and Dashwoods subzones. a) Layered troctolite cumulates from the Puddle Pond Complex. b) Layered gabbro from the Puddle Pond Complex. c) Fine-grained lherzolite intrudes very coarse-grained websterite in body near Whaleback Pond. Note the deformed nature of lherzolite. d) Wehrlite cumulate in body near Whaleback Pond.

have been dated by U-Pb ID-TIMS at the Geological Survey of Canada Geochronology laboratory. Analytical methods are outlined in Parrish et al. (1987). Heavy mineral concentrates were prepared using standard crushing, grinding, Wilfley ${ }^{\mathrm{TM}}$ table, and heavy liquid techniques. Mineral separates were sorted by magnetic susceptibility using a Frantz ${ }^{\mathrm{TM}}$ isodynamic separator. Analyzed single and multigrain zircon fractions were very strongly air abraded following the method of Krogh (1982). Treatment of analytical errors follows Roddick et al. (1987) with errors on the ages reported at the $2 \sigma$ level (Table 2). Concordia ages (Ludwig 1998) calculated for the samples presented in this paper (Fig. 3) incorporate errors on the decay constants and includes both an evaluation of concordance and equivalence of the data. The calculated Concordia ages and errors quoted in the text are at $2 \sigma$. Location of the dated samples is shown in Fig. 1 and in Table 2.

\section{VL02J294 - Puddle Pond complex(z7517)}

A sample of a gabbroic pegmatite from within the layered troctolite-olivine gabbro-gabbro sequence of the Puddle Pond complex (\# 1 in Fig. 1) contained zircons with varying morphologies, including colorless to brown anhedral fragments with conchoidal fractures and colorless to light brown prisms with aspect ratios of 2.5-5 (Table 2, Figs. 4a, b). Four analyzed fractions are near-concordant (-0.3 to $1.5 \%$ discordant) and define a Concordia age of $432.4 \pm 1.0 \mathrm{Ma}$ (MSWD of concordance and equivalence $=1.6$; probability $=0.14$; Fig. $3 \mathrm{a}$ ), which is interpreted to be the crystallization age of the gabbro. 

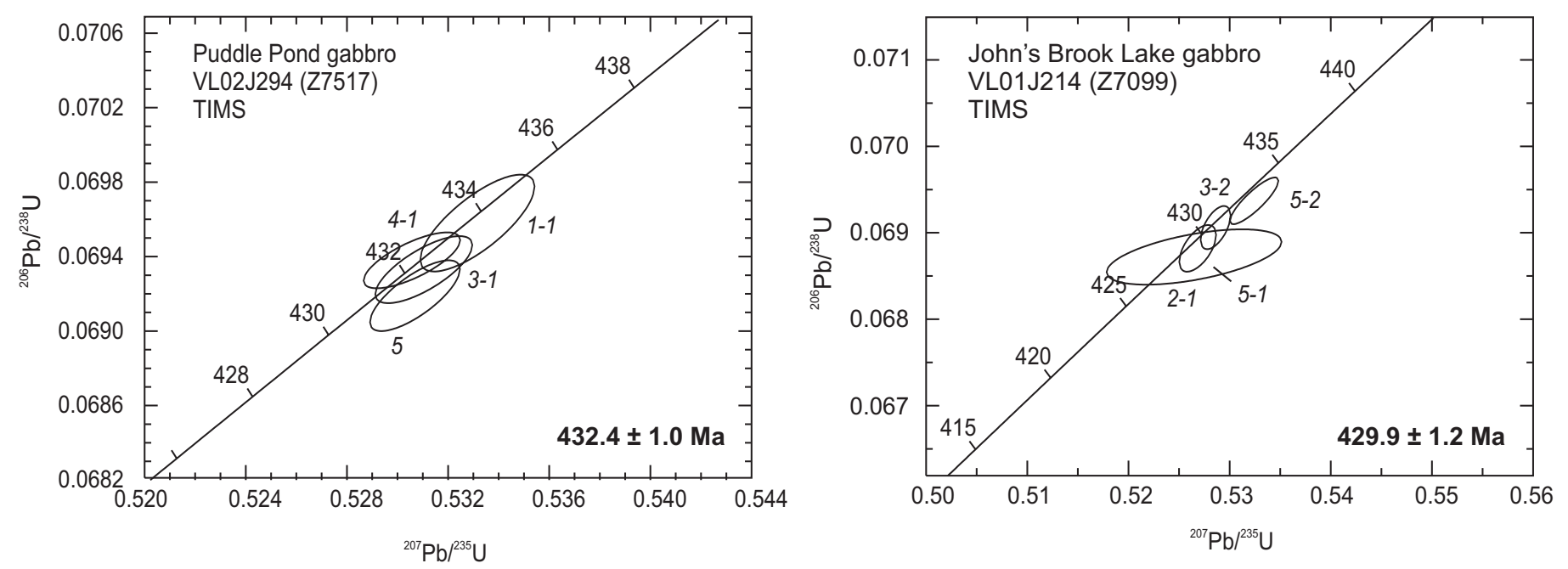

Fig. 3. Concordia diagrams for the Puddle Pond Complex and the John's Brook Lake gabbro.

\section{VL01J214 - John’s Brook Lake gabbro (z7099)}

A sample of pegmatitic gabbro of the John's Brook Lake gabbro (\#2 in Fig. 1), yielded zircons with both prismatic and anhedral habits (Table 2, Figs. 4c, d). A total of four fractions were analyzed, one of which (fraction 5-2) yielded slightly older ${ }^{206} \mathrm{~Pb} /{ }^{238} \mathrm{U}$ and ${ }^{207} \mathrm{~Pb} /{ }^{206} \mathrm{U}$ ages, suggesting the presence of a small amount of inherited material. The other three fractions, which are $0.6-1.5 \%$ discordant, were used to calculate a Concordia age of $429.9 \pm 1.2 \mathrm{Ma}$ (MSWD of concordance and equivalence $=1.3$; probability $=0.26$; Fig. $3 b$ ). This age is interpreted to be the crystallization age of the gabbro.

\section{DISCUSSION}

The Silurian ages of 432 and 430 Ma rule out the possibility that the gabbroic bodies are part of the Annieopsquotch ophiolite belt as inferred by Dunning and Herd (1980) and Dunning and Chorlton (1985). Their fresh nature, hydrous mineralogy, and ages indicate that they are part of the Silurian magmatic event that affected the Notre Dame and Dashwoods subzones between ca. 438-427 Ma (cf. Currie and van Berkel 1989). This magmatic episode has been attributed to slab break-off of the oceanic part of the Ganderian plate following its collision with the composite Laurentian margin (van Staal et al. 2003; Whalen et al. 2003). Silurian magmatism is dominated volumetrically by granite and rhyolite (Whalen 1989), but some mafic plutons have been described within the region (the Main Gut and Boogie Lake suites; Carew 1979; Currie and van Berkel 1989; Dunning et al. 1990). These have been dated at $431 \pm 2$ and $435+6 /-3 \mathrm{Ma}$, respectively (Dunning et al. 1990), in agreement with the ages presented herein. Our new data suggest that Silurian mafic plutons are both more widespread and volumetrically important than previously recognized. In addition, layered cumulate sequences form important parts of the Silurian suites.

The dominantly ultramafic bodies are of a different origin, because (1) the gabbroic bodies generally retain their igneous mineralogy, whereas the ultramafic bodies are metamorphosed, and (2) in general, ultramafic rocks, especially lherzolites, are not expected in plutons intruding continental crust. The occurrence of ultramafic cumulates and intrusive lherzolite strongly suggests an oceanic lower crustal affinity for these rocks. An ophiolitic origin is also consistent with their metamorphosed nature; both the Lushs Bight oceanic tract and Annieopsquotch ophiolite belt are metamorphosed at greenschist-to amphibolite-facies conditions. Petrogenetic grids for ultramafic rocks indicate that tremolite is stable above temperatures of ca. $500^{\circ} \mathrm{C}$, and is commonly associated with chlorite, olivine, and talc (Jenkins 1981). The presence of tremolite in most ultramafic rocks thus indicates that they were metamorphosed at amphibolite-facies conditions. The associated gabbros generally show amphibolite- to greenschistfacies mineral assemblages.

The ultramafic bodies occur on either side of the Lloyds River Fault Zone, the fundamental boundary that separates the Dashwoods Subzone from the Annieopsquotch Accretionary Tract (Fig. 1). The bodies at Whaleback Pond and Silver Pond, like those at Dennis Pond, Three Ponds, and North Fischells Brook (\#8-10 in Fig. 1), occur within the Dashwoods Subzone, suggesting a correlation between the two. The latter occur as enclaves in a migmatitic mélange that resembles the Mischief mélange (Fox and van Berkel 1988), and they occur along strike of the Long Range Complex, suggesting that these ultramafic bodies are relics of the Lushs Bight oceanic tract. This correlation is consistent with the similar metamorphic assemblages observed in the Long Range complex and the ultramafic bodies described herein (Table 1). We thus infer that all ultramafic bodies in the Dashwoods Subzone are relics of the Lushs Bight 


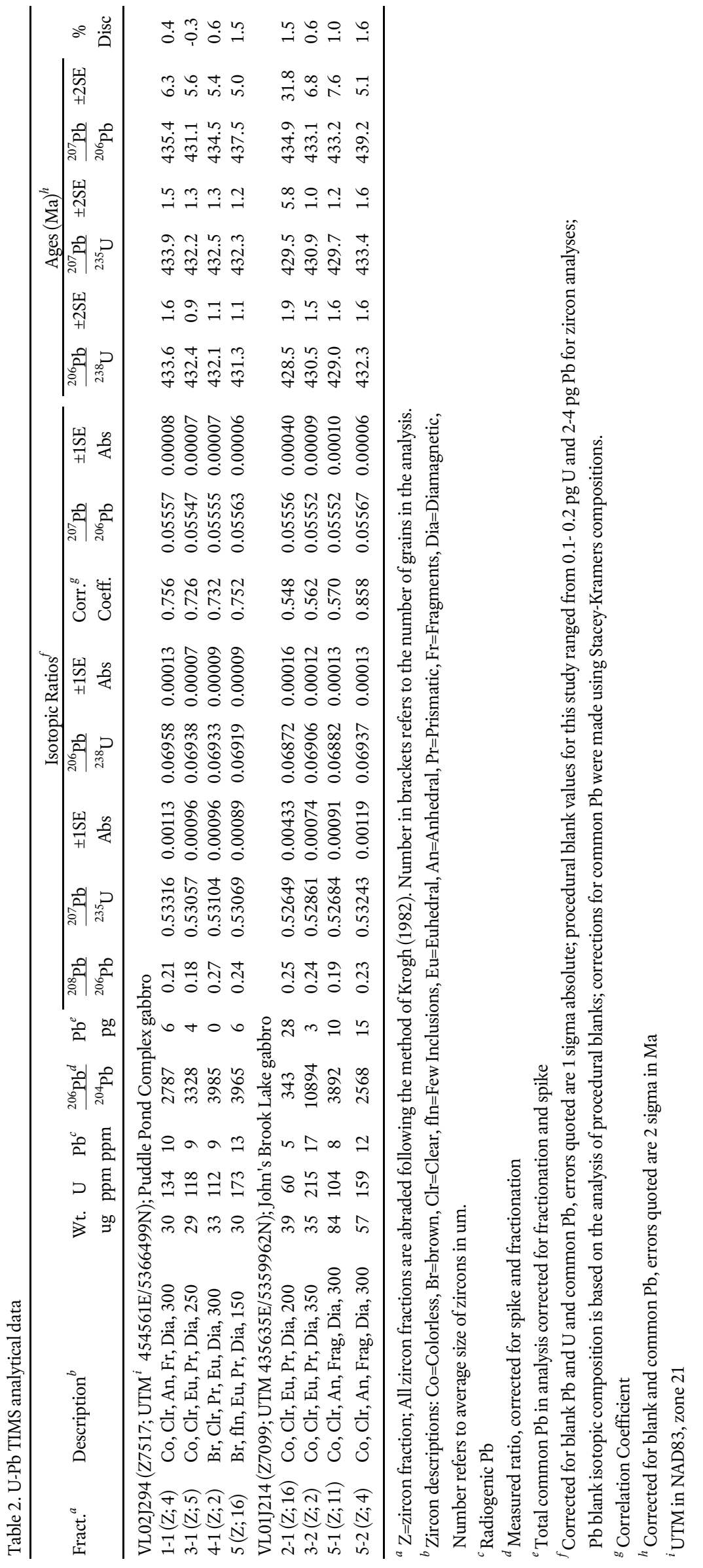



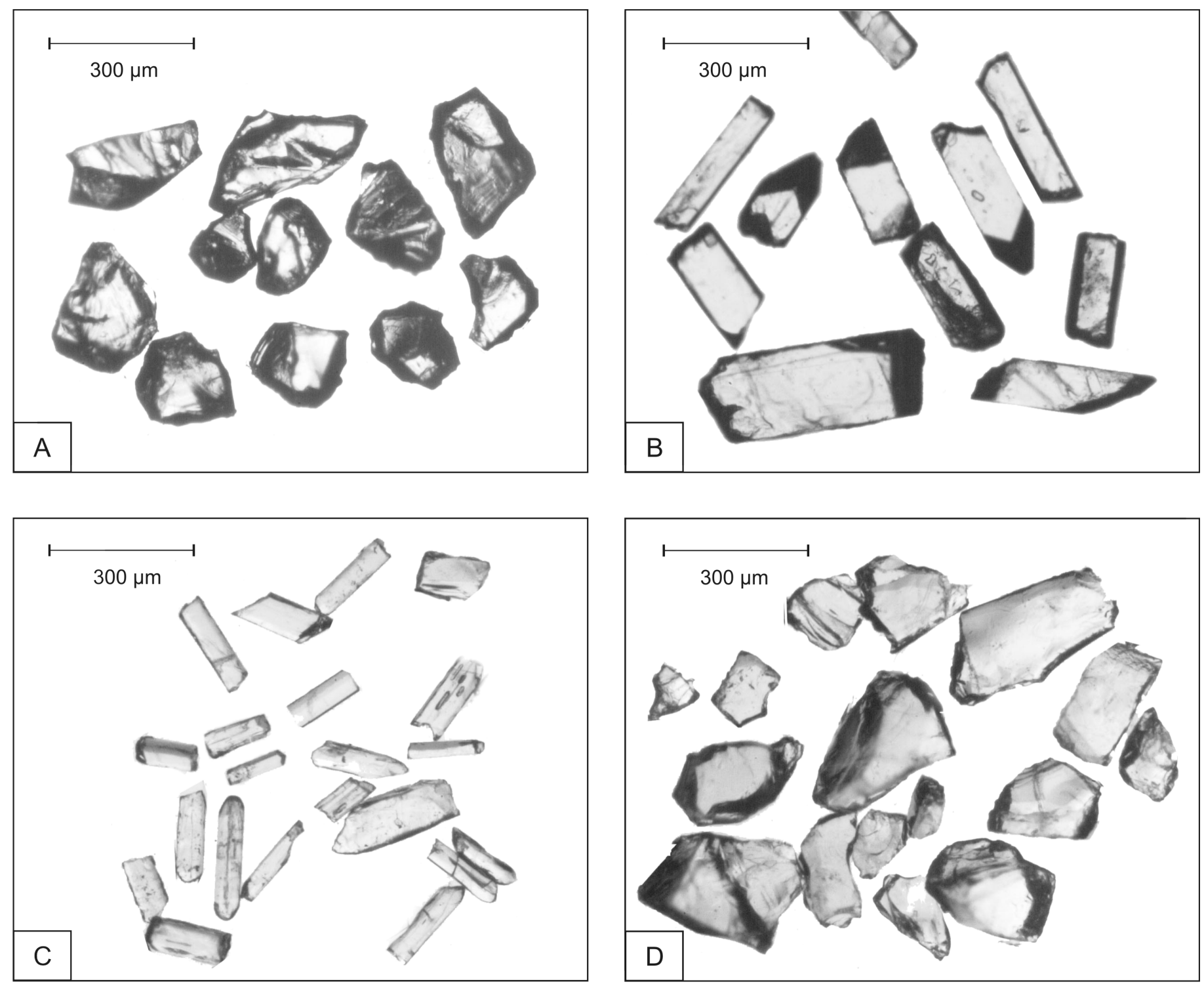

Fig. 4. Photomicrographs of zircon fractions of dated samples. a) Fraction I of the Puddle Pond complex; b) Fraction IV of the Puddle Pond complex; c) Fraction II of the John's Brook Lake gabbro; d) Fraction V of the John's Brook Lake gabbro.

oceanic tract. Their widespread occurrence indicates that the original extent of the Lushs Bight oceanic tract was much larger than currently preserved. We speculate that these ultramafic bodies are relics of a once continuous sheet of oceanic crust that was emplaced over the Dashwoods microcontinent. Parts of the sheet were dismembered during emplacement, and subsequent burial and intrusion by Ordovician and Silurian plutons has largely masked the ophiolitic cover, leaving only scattered ultramafic bodies in most of the Dashwoods and Notre Dame subzones.

The ultramafic bodies (Lloyds River, Padille Pond, Lake of the Hills) that occur within the Lloyds River Fault Zone are part of the Annieopsquotch Accretionary Tract, suggesting a genetic link with the Annieopsquotch ophiolite belt. Ultramafic lithologies are sparse in the Annieopsquotch ophiolite belt, but do occur within the Star Lake ophiolite and in the large ophiolitic massif to the west of it. The ultramafic rocks are confined to a thrust slice of the Annieopsquotch ophiolite belt that is bounded by the northwestern shear zone of the Lloyds River Fault Zone, and is separated from the main ophiolitic bodies by plutonic rocks that intruded the Lloyds River Fault Zone syn-kinematically (Fig. 1; Lissenberg and van Staal 2002; unpublished data). The higher abundance of ultramafic rocks within this thrust slice is consistent with the orientation of the pseudostratigraphy of the Annieopsquotch ophiolite, which suggests ultramafic lithologies should become more abundant to the northwest. The olivine-tremolite assemblages observed within the ultramafic rocks are consistent with the metamorphic grade recorded by amphibolite of the Lloyds River Fault Zone. We thus infer the ultramafic rocks within the Lloyds River Fault Zone represent stratigraphically deeper crustal levels of the Annieopsquotch ophiolite belt. 


\section{CONCLUSIONS}

Two types of mafic-ultramafic bodies occur within the northern Dashwoods Subzone and adjacent Lloyds River Fault Zone. Two gabbroic bodies and associated layered cumulates have been dated at $432.4 \pm 1.0$ and $429.9 \pm 1.2 \mathrm{Ma}$. They are interpreted to represent Silurian mafic magmatism related to slab break-off, suggesting that mafic magmatism was a more widespread and volumetrically important component of the Silurian magmatic event. In the absence of well-exposed contact relationships, Silurian plutons can be distinguished from ophiolitic enclaves on the basis of their lack of ultramafic rocks, fresher character, presence of associated hornblendedominated gabbros and presence of igneous hornblende and biotite in cumulates. Ultramafic rocks within the Lloyds River Fault Zone may be part of the Annieopsquotch ophiolite belt, whereas those occurring in the Dashwoods Subzone may represent equivalents of the Lushs Bight oceanic tract.

\section{ACKNOWLEDGEMENTS}

This work is funded by a scholarship from the Faculty of Graduate and Postdoctoral Studies, University of Ottawa, to C.J.L. and an NSERC grant to C.v.S in his position as Adjunct Professor at the University of Ottawa. We would like to thank Joe Whalen and Bill Davis for their thoughtful reviews prior to submission, and David Portsmouth and Max McGillen for able field assistance. Julie Peressini, Diane Bellerive and Carole Lafontaine are acknowledged for their assistance in the Geochronology lab. Comments by journal reviewers Scott Swinden and anonymous were also helpful. This is GSC contribution 2004287.

\section{REFERENCES}

Bédard, J.H., Lauziere, K., Tremblay, A., Sangster, A., Douma, S.L., \& Dec, T. 2000. Betts Cove ophiolite and its cover rocks, Newfoundland; Geological Survey of Canada Bulletin, 550, $76 \mathrm{p}$.

CAREW, W. 1979. A layered appinitic intrusion in Southwest Newfoundland: a field, petrographical and geochemical investigation. Unpublished B.Sc. thesis, Memorial University of Newfoundland, St. Johns, $53 \mathrm{p}$.

Cawood, P.A., van Gool, J.A.M., \& Dunning, G.R. 1996. Geological development of eastern Humber and western Dunnage zone: Corner Brook - Glover Island region. Canadian Journal of Earth Sciences, 33, pp.182-198.

CoIsh, R.A., \& СHURCH, W.R. 1979. Igneous geochemistry of mafic rocks in the Betts Cove ophiolite, Newfoundland. Contributions to Mineralogy and Petrology, 70, pp. 29-39.

Colman-Sadd, S.P., Hayes, J.P., \& KNight, I. 1990. Geology of the Island of Newfoundland; Geological Survey Branch,
Dept. of Mines and Energy, Government of Newfoundland and Labrador, scale 1:1.000.000.

Currie, K.L., \& van Berkel, J.T. 1989. Geochemistry of post-tectonic mafic intrusions in the Central Gneiss terrane of southwestern Newfoundland. Atlantic Geology, 25, pp. 181-190.

DeweY,J.F., \& BIRD, J.M. 1971. Origin and emplacement of the ophiolite suite: Appalachian ophiolites in Newfoundland. Journal of Geophysical Research, 76, pp. 3179-3206.

Dubé, B., Dunning, G.R., Lauziere, K., \& Roddick, J.C. 1996. New insights into the Appalachian orogen from geology and geochronology along the Cape Ray fault zone, southwest Newfoundland. Geological Society of America Bulletin, 108, pp. 101-116.

DunNing, G.R. 1981. The Annieopsquotch ophiolite belt, southwest Newfoundland. Current Research, Geological Survey of Canada Paper 81-1B, pp. 11-15.

Dunning, G.R., \& Chorlton, L.B. 1985. The Annieopsquotch ophiolite belt of southwest Newfoundland: Geology and tectonic significance. Geological Society of America Bulletin, 96, pp. 1466-1476.

DunNing, G.R., \& Herd, R.K. 1980. The Annieopsquotch ophiolite belt, southwest Newfoundland, and its regional relationships. Current Research, Geological Survey of Canada Paper 80-1A, pp. 227-234.

Dunning, G.R., \& KRoGH, T.E. 1985. Geochronology of ophiolites in the Newfoundland Appalachians. Canadian Journal of Earth Sciences, 22, pp. 1659-1670.

Dunning, G.R., Carter, P.J., \& Best, M.A. 1982. Geology of Star Lake (west half), southwest Newfoundland. Current Research, Geological Survey of Canada Paper 82-1B, pp. 21-26.

Dunning, G.R., O'Brien, S.J., Colman-Sadd, S.P., Blackwood, R.F., Dickson, W.L., O’NeILL, P.P., \& Krogh, T.E. 1990. Silurian orogeny in the Newfoundland Appalachians. Journal of Geology, 98, pp. 895-913.

Elliott, C.G., DunNing, G.R., \& Williams, P.F. 1991. New $\mathrm{U} / \mathrm{Pb}$ zircon age constraints on the timing of deformation in north-central Newfoundland and its implications for Early Paleozoic Appalachian orogenesis. Geological Society of America Bulletin, 103, pp. 125-135.

Fox, D., \& van Berkel, J.T. 1988. Mafic-ultramafic occurrences in metasedimentary rocks of southwestern Newfoundland. Current Research, Geological Survey of Canada Paper 88-1B, pp. 41-48.

HALl, L.A.F., \& VAN STAal, C.R. 1999. Geology of the southern end of the Long Range Mountains (Dashwoods Subzone), Newfoundland. Geological Survey of Canada Open File 3727, 1:50.000.

JENKINs, D.M. 1981. Experimental phase relations of hydrous peridotites modeled in the system $\mathrm{H}_{2} \mathrm{O}-\mathrm{CaO}-\mathrm{MgO}-\mathrm{Al}_{2} \mathrm{O}_{3}$ $\mathrm{SiO}_{2}$. Contributions to Mineralogy and Petrology, 77, pp. 166-176.

Jenner, G.A., Dunning, G.R., Malpas, J., Brown, M., \& Brace, T. 1991. Bay of Islands and Little Port Complexes 
revisited: Age, geochemical and isotopic evidence confirm supra-subduction zone origin. Canadian Journal of Earth Sciences, 28, pp. 1635-1652.

Karson, J.A., \& Dewey, J.F. 1978. Coastal Complex, western Newfoundland: and Early Ordovician oceanic fracture zone. Geological Society of America Bulletin, 89, pp. 1037-1049.

KrETZ, R. 1983. Symbols for rock-forming minerals. American Mineralogist, 68, pp. 277-279.

KROGH, T.E. 1982. Improved accuracy of U-Pb ages by creation of more concordant systems using an air abrasion technique. Geochimica et Cosmochimica Acta, 46, pp. 637-649.

Kurth, M., Sassen, A., Suhr, G., \& Mezger, K. 1998. Precise ages and isotopic constraints for the Lewis Hills (Bay of Island Ophiolite): Preservation of an arc-spreading ridge intersection. Geology, 26, pp. 1127-1130.

Lissenberg, C.J., \& van STAAL, C.R. 2002. The relationships between the Annieopsquotch Ophiolite Belt, the Dashwoods Block and the Notre Dame arc in southwestern Newfoundland. Current Research, Newfoundland Department of Energy and Mines, Geological Survey Report, 02-1, pp. 145-153.

Lissenberg, C.J., Zagorevski, A., Whalen, J.B., \& van StAAL, C.R. 2005 a. Geology, Star Lake, Newfoundland, 12A/11. Geological Survey of Canada Open File 1669, 1: 50.000 .

Lissenberg, C.J., Zagorevski, A., McNicoll, V.J., \& VAN StAal, C.R. 2005 в. Assembly of the Annieopsquotch Accretionary Tract, Newfoundland Appalachians: Age- and geodynamic constraints from syn- kinematic intrusions, Journal of Geology, 113, pp. 553-570.

LisSENBERG, C.J., van StaAl, C.R., BÉdard, J.H., \& ZAGOREVSKI, A. 2005 C. Geochemical constraints on the origin of the Annieopsquotch ophiolite. Geological Society of America Bulletin, 117, pp. 1413-1426.

LuDwIG, K.R. 1998. On the treatment of concordant uranium-lead ages. Geochimica et Cosmochimica Acta, 62, pp. 665-676.

MaLPAS, J. 1976. The petrology and petrogenesis of the Bay of Islands ophiolite suite, western Newfoundland. Ph.D. Thesis, Memorial University of Newfoundland, St. Johns, $432 \mathrm{p}$.

Parrish, R.R., Roddick, J.C., Loveridge, W.D., \& SullivAN, R.W. 1987. Uranium-lead analytical techniques at the Geochronology Laboratory, Geological Survey of Canada. Radiogenic age and isotope studies, Report 1, Geological Survey of Canada, paper 87-2, pp. 3-7.

Roddick, J.C., Loveridge, W.D., \& PARrish, R.R. 1987. Precise U-Pb dating of zircon at the sub-nanogram $\mathrm{Pb}$ level. Chemical Geology, 66, pp. 111-121.

Swinden, H.S., Jenner, G.A., \& SzYbinski, Z.A. 1997. Magmatic and tectonic evolution of the Cambrian-Ordovician Laurentian margin of Iapetus: Geochemical and isotopic constraints from the Notre Dame Subzone, Newfoundland. In The Nature of Magmatism in the Appalachian Orogen.
Edited by A.K. Sinha, J.B. Whalen, and J.P. Hogan. Geological Society of America Memoir v.191, pp. 337-365.

SzYBINSKI, Z.A. 1995. Paleotectonic and structural setting of the western Notre Dame Bay area, Newfoundland Appalachians. unpublished Ph.D. thesis, Memorial University of Newfoundland, St. John's.

Szybinski, A., House, S., \& Jenner, G.A. 1995. Stratigraphy and structure of the Glover Group, Grand Lake - Little Grand Lake area, Newfoundland. Current Research, Geological Survey of Canada 1995E, pp. 245-251.

UpadhyAY, H.D. 1973. The Betts Cove ophiolite and related rocks of the Snooks Arm Group, Newfoundland. Ph.D. Thesis, Memorial University of Newfoundland, St. John's, $224 \mathrm{p}$.

van Staal, C.R., Whalen, J.B., Pehrsson, S.J., \& McNicoll, V.J. 2003. Tectonic evolution of the Notre Dame magmatic arc, Newfoundland Appalachians. EOS Transactions of the American Geophysical Union, 84(46), Fall Meeting Supplement, Abstract V41A-06.

van Staal, C.R., Lissenberg, C.J., Pehrsson, S.J., ZagorevSki, A, Valverde-Vaquero, P., Herd, R.K., McNicoll, V., \& Whalen, J. 2005 a. Geology, Puddle Pond, Newfoundland (NTS 12-A/05). Geological Survey of Canada Open File 1664, scale 1:50.000.

van Staal, C.R., Valverde-Vaquero, P., Zagorevski, A, Boutsma, S., Pehrsson, S., van Noorden, M., \& V. McNiCOLL, 2005 в. Geology, King George IV Lake, Newfoundland (NTS 12-A/04). Geological Survey of Canada Open File 1665, scale 1:50:000.

van Staal, C.R., Zagorevski, A., Valverde-Vaquero, P., Rogers. N., \& Lissenberg, C.J. 2005 c. Geology, Victoria Lake, Newfoundland (NTS 12-A/06). Geological Survey of Canada Open File 1667, scale 1:50.000.

WaLdRon, J.W.F., \& van StaAL, C.R. 2001. Taconian orogeny and the accretion of the Dashwoods block: A peri-Laurentian microcontinent in the Iapetus ocean. Geology, 29, pp. 811-814.

Whalen, J.B. 1989. The Topsails igneous suite, western Newfoundland: an Early Silurian subduction-related magmatic suite? Canadian Journal of Earth Sciences, 26, pp. 2421-2434.

Whalen, J.B., Currie, K.L., van Breemen, O. 1987. Episodic Ordovician-Silurian plutonism in the Topsails igneous terrane, western Newfoundland. Transactions of the Royal Society of Edinburgh, 78, pp. 17-28.

Whalen, J.B., Jenner, G.A., Longstaffe, F.J., Robert, F., GARIEPY, C. 1996. Geochemical and isotopic (O, Nd, Pb and $\mathrm{Sr}$ ) constraints on A-type granite petrogenesis based on the Topsails igneous suite, Newfoundland Appalachians. Journal of Petrology, 37, pp. 1463-1489.

Whalen, J.B., Jenner, G.A., Longstaffe, F.J., Gariepy, C., \& FRYER, B.J. 1997. Implications of granitoid geochemical and isotopic $(\mathrm{Nd}, \mathrm{O}, \mathrm{Pb})$ data from the Cambrian-Ordovician Notre Dame arc for the evolution of the Central Mobile belt, Newfoundland Appalachians. In The Nature of Mag- 
matism in the Appalachian Orogen. Edited by A.K. Sinha, J.B. Whalen, and J.P. Hogan. Geological Society of America Memoir v.191, pp. 367-395.

Whalen, J.B., McNicoll, V.J., van Staal, C.R., \& Pehrsson, S.J. 2003. Plutonic rock geochemical and isotopic evidence for a transition from arc (ca. 489-435 Ma) to within-plate (ca. $430 \mathrm{Ma}$ ) magmatism within the Notre Dame arc. Geo- logical Society of America Abstracts with Programs, 35-3, p. 33 .

Williams, H., Colman-Sadd, S.P., \& Swinden, H.S. 1988. Tectonic-stratigraphic subdivision of central Newfoundland. Current Research, Geological Survey of Canada, 881B, pp. 91-98. 